\title{
特集：揮発性有機化合物 COMMENTARY
}

\section{呼気中バイオマーカーとしての揮発性有機化合物の質量分析}

\author{
Mass Spectrometry of Volatile Organic Compounds as \\ Biomarkers in Breath Analysis \\ 澤野 誠 1,2 \\ Makoto SAWANO \\ ${ }^{1}$ 埼玉医科大学教授 (救急医学) Acute Medicine, Saitama Medical University \\ ${ }^{2}$ 中部大学教授 (生命健康科学) Life and Health Science, Chubu University
}

(Received April 2, 2018; Accepted April 12, 2018)

\section{1. 呼気分析と質量分析}

呼気分析と医学の関係は意外と古く, 紀元前 400 年ごろ 医学の父といわれるヒポクラテスの著書に，すでに「呼気 の㫐いが，さまざまな疾患の診断の鍵となる」との記載が あり, 甘い果実 $\rightarrow$ 糖尿病, 腐った魚 $\rightarrow$ 肝臟病, 尿臭 $\rightarrow$ 腎臓 病など呼気臭と疾患の関連が指摘されている。しかし,こ の呼気（官能）分析の医学応用の端緒ともいうべき知識は 中世の闇に埋もれ，その再発見は 18 世紀後半の「近代化 学の父」といわれる Antoine Lavoisierによる呼気中二酸化 炭素の発見まで待たねばならなかった。その後相次いで乎 気中にアセトンやアルコールといった揮発性有機化合物 （Volatile Organic Compound: VOC）が発見され，近代分 析化学としての呼気分析の確立へとつながっていくことに なる ${ }^{1)}$.

一方，1900年代初頭にThomsonは，陰極線管を用いて 質量分析の端緒ともいうべき実験を行った ${ }^{2)}$.この装置で は陰極より陽極に向かって放出された電子が容器中の気体 原子と衝突し, 電子をたたき出すことによりイオンを生じ る. 生じたイオンは陰極に向かって加速されるが, 電場と 磁場を通過する際にその進路が曲げられ，その程度は $m / z$ に依存する.さらにAstonは, 軽い気体分子の動きは速く, 重い分子は遅い性質を応用し, 図1に示した質量分離装置 を開発し，ネオンをはじめとした多くの元素の安定同位体 を発見した。この質量分離装置の基本的な概念は，現在用 いられている質量分析計の源流となっている ${ }^{3)}$.

質量分析の呼気分析への応用の試みは早く, 1900 年代 末期の $\mathrm{Siri}^{4)} や \mathrm{Hunter}^{5)}$ らに遡る。1950年代後半に入り, この機運は欧米の呼吸生理学者の間で急速に高まり, 1960 年代にはFowlerらによる呼気分析を目的とした質量分析 計の開発が進んだ ${ }^{6}$. 本邦でも, やや遅れて1970年代に

連絡先：sawano@me.com
西らが同様の装置を開発し，呼気サンプリング法や分析条 件などの確立に寄与した ${ }^{7)}$ 。これらの装置は主に, 肺機能 の評価のために利用されていた。すなわち，生理的役割を 有するガス（酸素, 二酸化炭素, 窒素, 水蒸気) p呼吸機 能試験の際に被験者が吸入したテストガス（ヘリウム，ネ オンなど）の呼気中濃度の変動を測定することを主たる目 的としており，微量のVOCの測定や同定に用いられるこ とはなかった.

\section{2. 呼気中VOCの発見と質量分析計}

1970 年代初頭, 「近代分析化学の父」といわれる Pauling が, 当時分析化学の最先端技術であったガスクロマトグラ フィー（Gas Chromatography: GC）を用いて，呼気中には 200 種を超えるVOCが含まれていることを発見し，近代 分析化学としての呼気分析の発展の扉を開いた。この基盤 の上に, 1980 年代後半にPhillipsは, GCと質量分析計 （Mass Spectrometry: MS）を用いて呼気中VOCの分離・同 定に精力的に取り組み，呼気中バイオマーカー（診断の指 標となる生体物質）による医療診断の道を拓いた ${ }^{8)}$. Phillips は，75歳を超えた現在も乳がんの呼気診断を実用化する などトップランナーとして走り続けている.

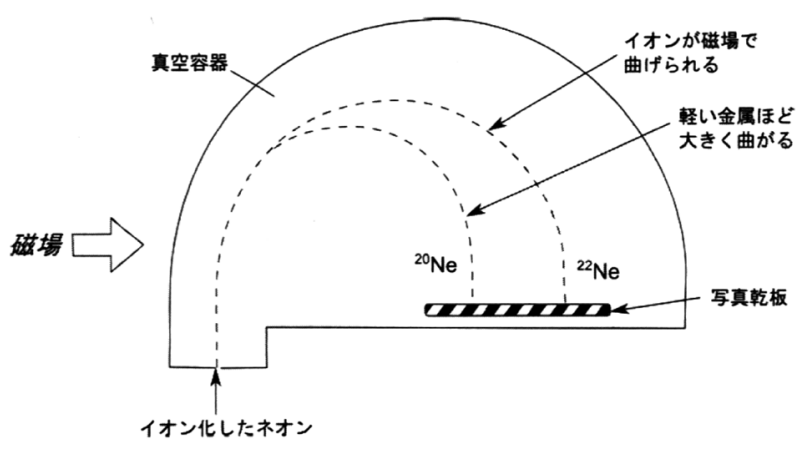

図1.Astonが考案した質量分離装置の概念図 (文献3より引用). 


\section{3. 呼気分析の基礎}

呼気を構成する物質（成分）は，その相からガス（気相）, ミスト（液相），パーティクル（固相）に大別される．飽 和した水蒸気を除いたガスの約 $80 \%$ は大気と同じく窒素 が占める。約 $16 \%$ は酸素が, 約 $4 \%$ は二酸化炭素が占め, さらに水素, 一酸化炭素 (CO), 一酸化窒素 $(\mathrm{NO})$, 硫 化水素 $\left(\mathrm{H}_{2} \mathrm{~S}\right)$, そして数百種類の VOCが極微量（ppm〜 ppbレベル）含まれる. ミストには吸入あるいは誤嘸された 液体成分, 唾液, そして respiratory（lining）fluid と呼ばれ る気道分泌液が含まれ, VOCならびに不揮発性有機化合 物（non-VOC）も含有される。パーティクルには主に，呼 吸に伴う肺胞レベルでの気道の開閉により放出される 1 ミ クロン径以下の微小な細胞塊や固形化した気道分泌物が含 まれるが，吸入された微粒子も混じる。

一方, 上記の乎気成分はその由来から, exposome, metabolome, microbiome, human metabolomeに大別される. Exposomeは気道や皮膚が暴露している, あるいは過去に 暴露した大気由来の物質である. Metabolomeは, 摂取し ている，あるいは過去に摂取した飲食物由来の物質であ る. Microbiomeは腸, 口腔, 気道に生息する微生物（細 菌, ウィルス, 真菌など) が産生する物質であり, $\mathrm{H}_{2}$ も これに含まれる. Human metabolomeは, 人体の細胞の代 謝活動により産生される物質であり, $\mathrm{CO}_{2}$ 以外にも CO, $\mathrm{NO}, \mathrm{H}_{2} \mathrm{~S}$ などの内因性ガスや多種類のVOCが含まれる. このように, 呼気中にはさまざまな由来の物質が混在し, 医療診断に有望な物質がある一方で, 目的とする物質の測 定を妨げる污染物質も含まれ，呼気分析におけるサンプリ ングおよび測定の難しさにつながっている.

呼気には, 大量の検体（サンプル）を, 全く無侵襲に (時には被験者が意識することもなく)・随時・繰り返し採 取できるという大きな利点がある。一方で，その採取（サ ンプリング）にはいくつかの重大な問題点あるいは難点が ある。呼気採取の最大の問題点は, サンプルの質の確保が 困難なことである．例えば，呼気中の特定の物質の濃度は， 大まかに血中濃度, 換気量そして心拍出量（肺動脈血流量） により規定されるが, 呼気の採取を意識した途端に被験者 の換気量が増加する（過換気になる）ことはよく知られて いる.したがって, 複数サイクルの呼気採取を行う場合に は, 心拍数や気道内圧を監視しつつ, メトロノームを用い て換気回数（量）を一定にする“Paced sampling”などの 厳密な採取法が実践される。また, 呼気の成分・組成は呼 吸相により複雑かつ大幅に変動する。呼気のサンプルとし ては, 多くの場合に終末呼気（息を吐き終わる直前の呼気） が物質の血中濃度を反映することが知られている。そこで, 呼気中二酸化炭素濃度を指標として終末呼気を採取する “ $\mathrm{CO}_{2}$ triggered sampling” などの採取技術が取り入れられ る.このように, 複数回採取された呼気サンプルの質は, 単回採取の呼気サンプルのそれとは全く異なるという事実 を認識することが重要である。

しかし一方で, 多数の被験者から短時間に呼気を採取す
る場合など，単回呼気採取とならざるをえない場合もある. このような場合には “Critical flow orifice”などの呼出抵抗 を増大させる装置を用いて, 連続的に呼出圧 (Pex) と呼気 二酸化炭素濃度 $\left(\mathrm{cCO}_{2}\right)$ をモニタリングする。ここで呼気 サンプルの質は, Pexの変動 (=標準偏差) と $\mathrm{cCO}_{2}$ の変動 (=標準偏差）の積として表され，これを評価して質の確 保を行う.

呼気分析において，呼気サンプルの質を確保することは 前提であるが，分析を実行するまでの間のサンプルの保存 も同様に重要である．安定した物質の場合には，市販され ている呼気サンプルバッグ（尿素呼気試験用）にて一定期 間保存可能であるが，VOCのように不安定な物質や水へ の溶解度の高い物質の場合には, 保存中の変化や温度に留 意する必要がある。その意味では，呼気の採取と分析を同 時に行うオンライン測定が理想的と言える。オンライン測 定は, 医療現場 (Point of care) での検査・診断という最新 の医療技術の方向性にも合致する.

\section{4. 呼気中VOCの分析・計測技術}

乎気中のガスやVOCの分離定量の基本はガスクロマト グラフィー (GC) である. GCでは, カラムの入り口にサン プルガスを注入し，一定流量のキャリアガス（ヘリウムや 窒素など）を供給しながら，カラム基剤との相互作用の強 弱により物質を分離し，各々の保持時間（Retention Time: RT）における検出器の信号強度（ピーク面積）をもとに定 量する。二つの異なる性質のカラムを併用して分離能を向 上させた 2 次元 GCも実用化されている.

GCによって分離された物質を質量分析（MS）する際は 通常, 電子イオン化が使われる. 電子イオン化によって生 成した分子イオンとフラグメントイオンの $m / z$ を測定する ことで, 質量スペクトル (Mass spectrum) が得られる.こ れを質量スペクトルのデータベース（Library）と照合する ことで，目的物質を同定する．時には，異性体の判別も可 能となる。よってGC-MSは, サンプルに含有される微量 物質を網羅的に分離・同定・定量することが可能である. このような特長を活かし, GC-MSは医療診断につながる 呼気中バイオマーカーの候補となるVOCの探索において 主力分析手法となっている.

さらに質量分析計は, 特定の $m / z$ のイオンだけを選択す る高精度なフィルターとして用いることも可能である。こ の原理を応用し, 目的物質の一次イオン（Precursor ion） から衝突・解離で生成した二次イオン（Product ion）を限 定的に検出するため, 三連四重極型質量分析計を用いた Multiple reaction monitoring（MRM）により，選択性と感 度（S/N比）を格段に向上させた GC-MS/MS も実用化され ている。

\section{GC-MSによる呼気中VOC分析の実際}

$\mathrm{ppm} \sim \mathrm{ppb}$ レベルの乎気中VOCを分離・同定・定量する 目的において，いきなり呼気バッグに採取した検体を気体 用シリンジにて GC-MSに注入したのでは，いかに高感度・ 


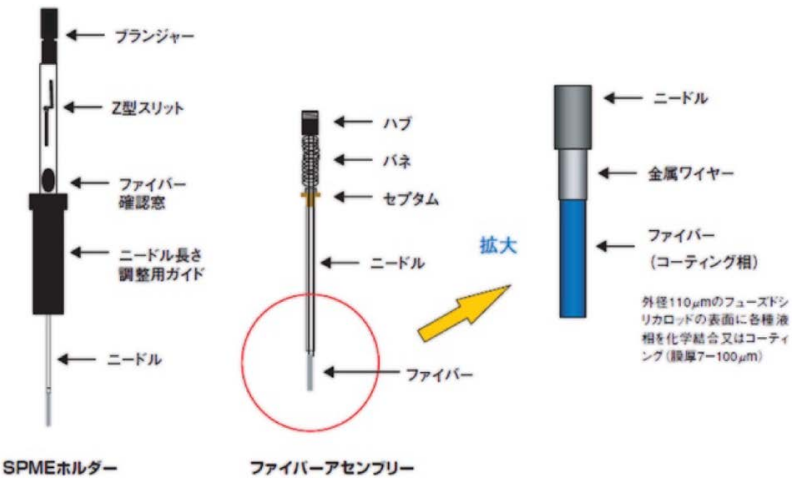

図2. SPME装置 (SPME針) の構造（文献10より引用).

高分離能を誇る GC-MS とはいえ評価に耐える結果は得ら れない，適切な前処理（濃縮）が不可欠である.1990年代 までの気体サンプル中VOC測定の前処理（濃縮）法とし ては, 活性炭管を用いる固相吸着・溶媒抽出法や Tenax管 などを用いる固相吸着・加熱脱着法が一般的であった ${ }^{9)}$. しかし, これらの前処理法は, 長時間にわたる多段階の試 料脱着操作が必要であった。よって現在では, より簡便な 固相マイクロ抽出法 (Solid phase micro extraction: SPME) が主として用いられる。

図2に示したSPME装置 (SPME針) は, 外筒おょび出し 入れの可能な内針からなる外套針であり, 内針にはポリジ メチルシロキサン (Polydimethylsiloxane: PDMS) などの吸 着剂がコーティングされている ${ }^{10)}$. 以下の手順にて, 呼気 サンプル中のVOCの前処理（濃縮）を行う.

(1) 呼気バッグ内部の水分が結露しVOCが溶解しないよ うに, バッグを 40 度前後に加温する.

(2) SPME針を吸着剤がコーティングされている内針が外 筒に隠れる状態で, 呼気バッグの気密性を保ったまま 直接挿すする。

(3) 吸着剂がコーティングされている内針を呼気サンプル 中に露出させ，5１5分間VOCを吸着する。

(4) 内針を外筒内に収納し, SPME針を呼気バッグより抜 去する。

(5) SPME針を250度に加熱されたGC-MSの注入ポート （オーブン）内に挿入，内針を高温のキャリアガス中 に露出して吸着・濃縮されたVOCを加熱脱着する。

図3の上段には, 健常人の呼気サンプルを前処理なしに 直接 GC-MSに注入して得られる全イオン電流クロマトグ ラフ（Total Ion-current Chromatograph: TIC）を，下段に は同一サンプルについてSPME法による前処理（濃縮）を 行った場合の TICを示した。前処理を行うと, 前処理なし の場合と比較して, 压倒的に多数のピークが分離され，か つ夾雑（ノイズ）が低下し，VOCに対する感度・選択能 ともに大幅に向上する。しかし定量測定の際には, 個々の VOCにより吸着能すなわち濃縮率が異なることに留意す る必要がある.

最後に, 呼気中VOCのGC-MS 分析の実用例として, 受 動喫煙の影響の評価を目的とした喫煙者の呼気分析を紹介

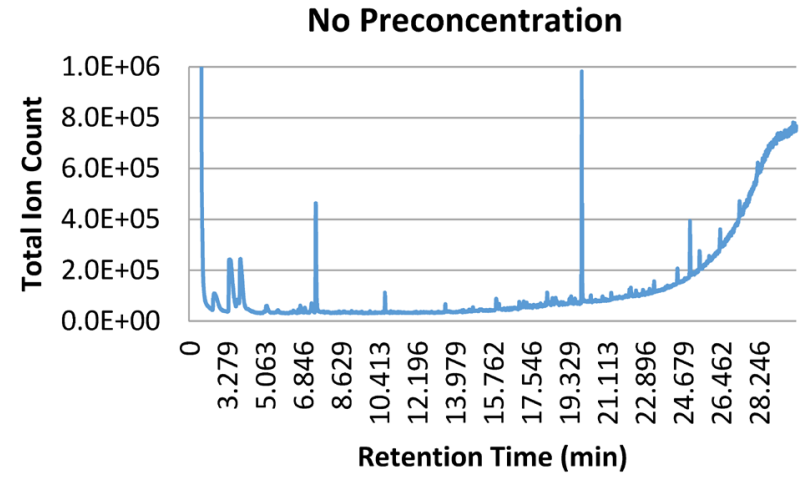

Preconcentration with SPME

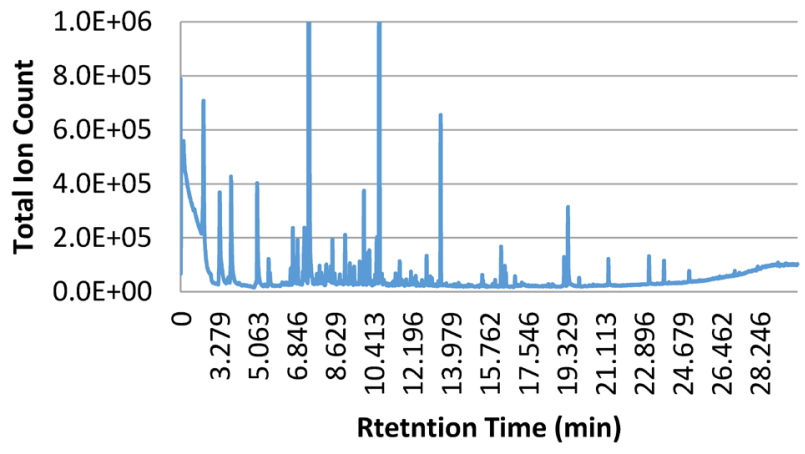

図3.上段：健常人の呼気サンプルを前処理なしに直接 GCMS に注入して得られる全イオン電流クロマトグラフ (TIC). 下段：同一サンプルについてSPME法による 前処理（濃縮）を行った場合のTIC.
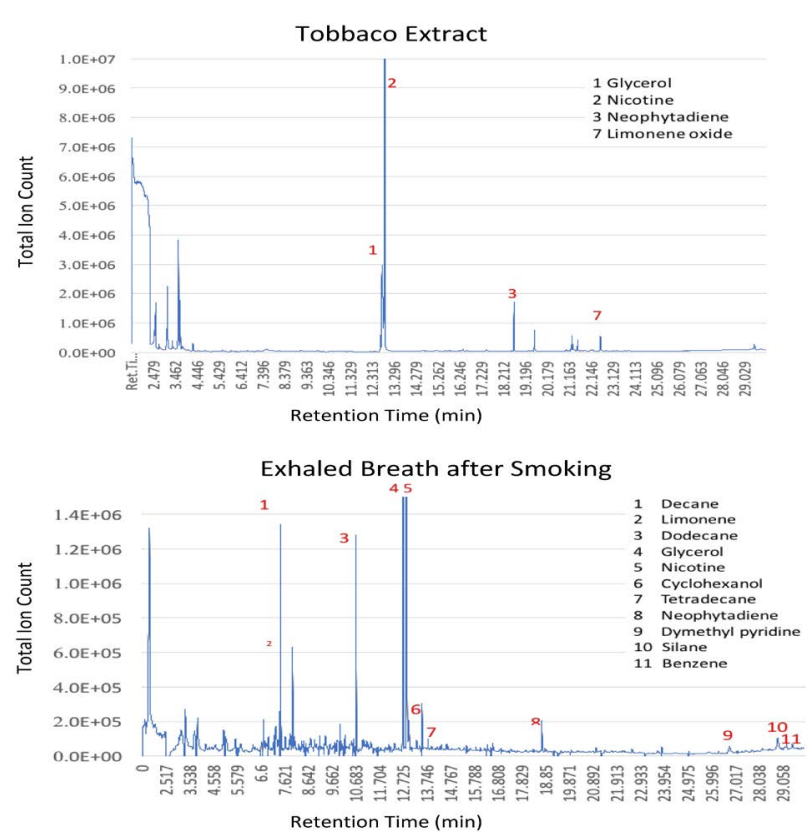

図4. 上段：一般的な紙巻きタバコに含有されるVOCのトー タルイオンクロマトグラムと同定結果. 下段：紙巻き タバコを喫煙した後に採取した呼気に含まれる二次生 成VOCのトータルイオンクロマトグラムと同定結果.

する. 図4の上段には，一般的な紙巻きタバコに含有され るVOCをメタノールにて抽出し，これを直接GC-MSに注 入して得られたTICを示した. グリセロール，ニコチン， ネオフィタディエン，酸化リモネンなどのピークが認めら 
れる.図4の下段には，この紙巻きタバコを喫煙した後に採 取した呼気サンプルをSPME法にて前処理（濃縮）し GC-MS 分析して得られたTICを示す。なおここでは, 喫煙前に採 取した呼気サンプルのTICを差し引いており，契煙により 新たに出現したピークが表示されている. 喫煙後の呼気か らは, 紙巻きタバコに含有されるVOC以外にも, これらの VOCが加熱・燃焼および人体に暴露されることで新たに (=二次的に) 生成した化合物が分離・同定された。これら 二次生成 VOCには, デカン・ドデカンなどのアルカン類 をはじめとする有害物質が多数含まれており, 受動喫煙に よる健康被害の原因となっていることが明らかになった。

\section{6. 呼気中 VOC 分析と医療診断の現状}

初期の期待に反して, 過去四半世紀にわたり, 特定疾患 の診断につながる呼気バイオマーカーとしてのVOCの探 索はことごとく失敗に終わっていると言っても過言ではな い. 近年では, 単一の呼気バイオマーカーによる医療診断 については絶望視されており, 多数の選択性や応答性の異 なる微小センサーを一つのチップ上に配列したセンサー・ アレイとニューラル・ネットワークなどの機械学習を組み 合わせた電子嗅覚センサー（Electronic nose）の医療診断へ の応用が期待されている ${ }^{11)}$. GC-MSに代表される従来の 呼気分析技術による医療診断は, 呼気中の多種多様な VOC を一つずつ分離・同定したうえで定量し, 特定の疾患の罹 患者と非罹患者を比較することにより, 各々のVOCに対し てバイオマーカーとしての有用性を検討するものである. 一方, 電子嗅覚センサーは, 個別の VOCに注目するので はなく, 多種のVOCの相対的な分布や変動をパターンと して認識・処理する探索的技術である。この技術には, 人 間を含めた動物の嗅覚認識の生理学的機序に近いことから “Electronic nose”という名称がつけられたが, 今後の呼気 分析による医療診断の動向にも合致しており, 大きな期待 が持たれている．現実に乳がんや肺がんの呼気診断のよう に一部はすでに実用化され臨床応用も始まっている。しか
し, 電子嗅覚センサーの診断精度の検証や, 生理学的・病 理学的裏付けには，GC-MSを用いた個々の呼気中VOCの 変動の解析および標準化が不可欠である.

一方，安定同位体である ${ }^{13} \mathrm{C} に て$ 標識された有機化合物 を投与し, 呼気中 ${ }^{13} \mathrm{CO}_{2}$ の経時的変動より, 消化管運動, 消化吸収機能, 薬物代謝などを測定する ${ }^{13} \mathrm{C}$ 化合物負荷呼 気試験は，呼気分析による医療診断として最も早く臨床応 用や普及が進んだ検査法である。呼気中 ${ }^{13} \mathrm{CO}_{2}$ と ${ }^{12} \mathrm{CO}_{2}$ の存 在比（同位体比）の測定には，当初は原理的に同位体分析 に適した質量分析計が用いられてきた。しかし近年では, 安価でコンパクトな赤外線分光法による $\mathrm{CO}_{2}$ 同位体比測定 装置が普及し，小型化が進んだとはいえ測定準備やメンテ ナンスが煩雑な質量分析計にとって替わったと言っても過 言ではない。 ${ }^{13} \mathrm{C}$ 化合物負荷呼気試験は, 呼気バイオマー カーとしてのVOCの探索と比較して，呼気検体の採取・ 保存や測定法のクオリティー・コントロール，そしてバッ クグラウンドの排除が容易であることが特長であり，臨床 応用や普及が早かったことの要因である.

\section{文献}

1）澤野 誠, 空気清浄：コンタミネーションコントロール, 54(5), 329 (2017).

2) J. J. Thomson, Proc. R. Soc. Lond. A, 89, 1 (1913).

3）熊本卓哉, 化学と教育, 61(2), 70 (2013).

4) W. Siri, Rev. Sci. Inst., 18, 540 (1947).

5) J. A. Hunter, R. W. Stacy, and R. A. Hitchcock, Rev. Sci. Inst., 20, 332 (1949).

6) K. T. Fowler, Phys. Med. Biol., 14, 185 (1969).

7) 西 功, 応用物理, 43(4), 372 (1972).

8) M. Phillips, Anal. Biochem., 247 (2), 272 (1997).

9) The Japan Ministry of Health, Labour, and Welfare, Committee on Sick House Syndrome, Indoor Air Pollution Progress Report No. 1 (2000).

10) Sigma-Aldrich 社 HP https://www.sigmaaldrich.com/japan/ analytical-chromatography/sample-preparation/spme.html\#01 (2018.3.29閲覧)

11) A. K. Pavlou and A. P. Turner, Clin. Chem. Lab. Med., 38(2), 9 (2000). 